\title{
PERLINDUNGAN HUKUM BAGI PENANAMAN MODAL ASING (PMA) DI INDONESIA
}

\author{
Oleh: \\ Ria Sintha Devi \\ Universitas Darma Agung \\ E-Mail: \\ riasinthadevi04@gmail.com
}

\begin{abstract}
The existence of Foreign Investment in Indonesia is very important and strategic in supporting the implementation of national economic development and increasing economic growth in the community. Foreign investment which is regulated in law No. 25 of 2007 about the legal protection for foreign investment in Indonesia, both investment in the form of a Limited Company (PT) or investment. This shows that foreigners in Indonesia who carry out their capital investment activities are regulated by law and protected by the government under the law. The formulation of the problem were how the position of the establishment of foreign investment companies in Indonesia was, what the procedures for the implementation of foreign investment in Indonesia were, and what efforts have been made by the government if there were violations of law in foreign investment in Indonesia. The results of the study showed every foreign company that wanted to invest in Indonesia had to get the principle permission to the Investment Coordinating Board (BKPM) and the One Stop Integrated Investment and Services Office (PTSP), so that the company could be established in Indonesia and its establishment was in accordance with the procedures of the law on foreign investment so that the foreign investment company was fully under the responsibility and supervision of the Republic of Indonesia. The government also gave relief to foreign investment in Indonesia in freeing the entry tax fees for goods or electronic equipment for foreign investment (PMA) in Indonesia in investing their capital.
\end{abstract}

Keywords: Legal Protection, Foreign Investment

\section{PENDAHULUAN}

Penanaman modal diartikan sebagai kegiatan pemanfaatan dana yang dimiliki dengan menanamkanya ke usaha / proyek yang produktif baik secara langsung maupun tidak langsung, dengan harapan selain mendapatkan pengambilan modal awalnya di kemudian hari, tentunya pemilik modal juga akan mendapatkan sejumlah keuntungan dari penanaman modal di maksud.

Penanaman Modal merupakan segala kegiatan menanamkan modal, baik oleh penanam modal dalam negeri maupun Penanam Modal Asing untuk melakukan usaha di wilayah negara Republik Indonesia. Penanaman Modal Asing dalam tulisan ini selanjutnya disebut PMA. Indonesia sebagai sebuah negara kepulauan yang memiliki sumber daya alam melimpah dari pertanian, peternakan, perikanan, kehutanan, maupun pertambangan. Tidak serta merta sumber daya alam melimpah, dapat diambil dengan sendirinya ataupun diolah. 
Untuk itu, timbulnnya keinginan untuk menarik investor, yang dimulai sejak jaman orde baru hingga sekarang. Tetapi Pada pertengahan tahun 1997 Indonesia mengalami krisis moneter. Defresiasi nilai tukar rupiah makin tajam sehingga krisis moneter yang terjadi tersebut berlanjut menjadi krisis ekonomi yang dampaknya terasa hingga saat ini.Sehingga investor asing enggan menaruh investasinnya lagi dan Pertumbuhan ekonomi berjalan sangat lambat.

Salah satu cara untuk membangkitkan atau menggerakkan kembali perekonomian nasional seperti sediakala sebelum terjadinya krisis ekonomi adalah kebijakan mengundang masuknya investasi di Indonesia. Investasi, khususnya investasi asing sampai hari ini merupakan faktor penting untuk menggerakkan dan mendorong pertumbuhan ekonomi. Harapan masuknya investasi asing dalam kenyataannya masih sulit untuk diwujudkan.

Bahan pertimbangan investor dalam menanamkan modalnya, antara lain : Pertama faktor Sumber Daya Alam, Kedua faktor Sumber Daya Manusia, Ketiga faktor stabilitas politik dan perekonomian, guna menjaminkepastian dalam berusaha, Keempat faktor kebijakan pemerintah, Kelima faktor kemudahan dalam perizinan.

Di era reformasi, Pemerintah justru berupaya menarik sebanyak mungkin investasi asing melalui rentetan kunjungan kenegaraan ke luar negeri, privatisasi BUMN, penegakkan supremasi hukum, serta revisi terhadap berbagai undang-undang yang menyangkut bisnis dan investasi perpajakkan, ketenagakerjaan dan seterusnya. Semua upaya ini tentu bertujuan menciptakan iklim dunia usaha dalam negeri yang lebih kondusif demi meningkatkan capital inflow yang pada gilirannya diharapkan meningkatkan kesejahteraan rakyat.

Pentingnya peranan penanaman modal asing dalam pembangunanan ekonomi Indonesia juga teefleksi dalam tujuan yang teterai dalam undang-undang No. 25 Tahun 2007 tentang penanaman modal (UU Penanaman Modal) sebagai landasan hukum positif bagi kegiatan penanaman modal di Indonesia. Dalam UU penanaman modal di sebutkan antara lain:

1. Meningkatkan pertumbuhan ekonomi nasional.

2. Menciptakan lapangan kerja.

3. Meningkatkan pembangunan ekonomi berkelanjutan.

4. Meningkatkan kemampuan daya saing dunia usaha nasional.

5. Menigkatkan kapasitas dan kemampuan dan teknologi nasional.

6. Mendorong pengembangan ekonomi kerakyatan.

7. Mengolah ekonomi potensial menjadi kekuatan ekonomi rill dengan menggunakan dana yang berasal, baik dalam negeri maupun dari luarnegeri.

8. Meningkatkan kesejahteraan masyarakat.

Peningkatan penanaman modal asing di indonesia tidak datang dengan sendirinya. Hal itu memerlukan kerja keras untuk dapat menciptakan iklim investasi yang kondusif. Salah satu isu klasik yang sangat signifikan dalam menciptakan iklim investasi yang kondusif di Indonesia adalah masalah penegakan hukum (law enforcement), di samping masalah-masalah lainnya, seperti keterbatasan infrastruktur, keamanan, dan stabilitas sosial politik. 
Dalam melakukan penegakan hukum (law enforcement) terdapat tiga unsur yang harus diperhatikan: Kepastian Hukum, kemanfaatan , dan keadilan yang harus berjalan secara humoris. Apabila penegak hukum hanya memerhatikan kepastian hukum semata, maka pelaksanaannya dapat mengabaikan keadilan serta kemanfaatannya di masyarakat, begitupula sebaliknya apabila salah satu unsur tersebut terlalu diutamakan, maka pelaksanaannya dapat mengabaikan unsur-unsur lainnya.

Perlindungan hukum merupakan mencari segala upacaya yang menjadi kepastian hukum. Perlindungan hukum juga memberikan pengayoman kepada hak asasi manusia yang dirugikan orang lain dan perlindungan tersebut diberikan kepada masyarakat agar mereka dapat menikmati semua hak-hak yang diberikan oleh hukum atau dengan kata lain perlindungan hukum adalah berbagai upaya hukum yang harus diberikan oleh aparat penegak hukum untuk memberikan rasa aman, baik secara pikiran maupun fisik dari gangguan dan berbagai ancaman dari pihak manapun. Perlindungan yang diberikan oleh hukum, terkait pula dengan adanya hak dan kewajiban, dalam hal ini yang dimiliki oleh manusia sebagai subyek hukum dalam interaksinya dengan sesama manusia serta lingkungan. Dua hal yang mempengaruhi kegiatan FDI di suatu negara, yang pertama yaitu lingkungan atau kerangka kebijakan suatu negara. Kondisi suatu negara menjadi salah satu hal yang paling penting sebelum menetapkan negara tersebut menjadi lokasi invertasi. Kerangka kebijakan ini dalam beberapa hal, yaitu:

a. Stabilitas ekonomi, politik dan social. b. aturan yang mendukung masuk dan operasinya suatu usaha

c. standar kesepakatan internasional

d. kebijakan dalam memfungsikan dan struktur pasar

e. persetujuan internasional dalam FDI (Foreign Direct Investment/FDI) dimana FDI merupakan investasi yang dilakukan swasta asing ke suatu negara, berupa cabang perusahaan multinasional, anak perusahaan multinasional, lisensi, joint ventura.

f. kebijakan privatisasi dan

g. kebijakan perdagangan dan perpajakan.

Badan Koordinasi dan Penanaman Modal (BKPM), telah melakukan upaya untuk meningkatkan Investasi langsung di Indonesia, diantaranya sebagai berikut:

a. Pemerintah telah memperbaharui Daftar Bidang Usaha yang Tertutup bagi Penanam Modal untuk dapat diberikan keleluasaan investor dalam memilih usaha (Keppres No 96 Tahun 2000 jo. No 118 Tahun 2000). Dalam keputusan tersebut, bidang usaha yang tertutup untuk investasi baik PMA maupun PMDN berkurang dari 16 sektor menjdai 11 sektor.

b. Penyederhanaan proses dari 42 hari menjadi 10 hari. Persetujuan PMA cukup dilakukan oleh Pejabat Eselon I, dalam hal ini yang berwenang adalah Deputi Bidang dan Fasilitas Penanaman Modal;

c. Sejak tanggal 1 Januari 2001, pemerintah menggantikan insentif Pembebasan Pajak dengan Kelonggaran Pajak 
Investasi sebesar $30 \%$ untuk 6 (enam) tahun.

d. Nilai investasi tidak dibatasi, sepenuhnya tergantung studi kelayakan dari proyektersebut.

Perkembangan PMA di Indonesia/Perkembangan FDI di Indonesia sangat dipengaruhi oleh situasi diluar negeri maupun didalam negeri. Perkembangan investasi di Indonesia sering bergerak tidak menentu terutama jika lingkungan investasi dalam negeri kurang kondusif.

Menurut daftar yang dikeluarkan oleh UNCTAD Indonesia sebetulnya termasuk negara yang menarik bagi para investor. Terutama bagi TNC's (transnational companies); yaitu para investor yang berskala besar. Tahun 2011 Indonesia menempati tempat ke 4 setelah China, USA, dan India, menurut survey dari UNCTAD. Negara-negara berkembang lainnya yang termasuk dalam daftar UNCTAD ialah: Brazil, Meksiko, Thailand, Vietnam, Korea Selatan dan Malaysia. Sebaliknya, walaupun dalam daftar UNCTAD Indonesia termasuk negara-negara yang secara potensial menarik tetapi dilihat dari angka-angka Sekretariat ASEAN, Indonesia hanya menempati tempat yang rendah di ASEAN; yaitu tempat ke-5 dari 10 negara.

Contoh Kasus PMA di Indonesia UU tentang Penanaman Modal Asing yang diberlakukan tahun 2007 silam, semakin menyiratkan bahwa pemerintah tidak berdaya menolak intervensi dan kepentingan asing. Krisis moneter Tahun 1997 mengakibatkan terjadinya, PT Aqua pertumbuhan dibawah $30 \%$. Hal itu disebabkan perusahaan hanya menghasilkan laba bersih sebesar Rp 7.8 milyar atau turun sebesar $25 \%$ dibandingkan dengan tahun 1996. Oleh karena itulah, PT Aqua memutuskan untuk menjual sebagian sahamnya kepada investor asing dalam hal ini adalah French Danone, dengan jalan melakukan akui sisi saham. Akui sisi saham terjadi ketika sebuah perusahaan mengakui sisi saham berhak suara dari perusahaan lain dan kedua perusahaan tersebut tetap beroperasi sebagai entitas hukum yang terpisah, akibatnya muncul perusahaan induk dan perusahaan anak.

Pengambil alihan itu sempat menggemparkan banyak pihak, pasalnya Aqua merupakan perusahaan Air Minum Dalam Kemasan (AMDK) yang memiliki jumlah penjualan terbanyak dan paling terkenal. Bagi Danone, Aqua jelas merupakan AMDK yang menguntungkan.

Penanaman Modal Asing juga memberikan berbagai keuntungan bagi penanaman modal di Indonesia. Keuntungan-keuntungan yang dapat diperoleh dengan adanya PMA diantaranya adalah:

1. Produksi-produksi beberapa produk kebutuhan rakyat banyak dengan maksud untuk di ekspor (dengan penggunaan bahan baku yang umumnya terdapat di tanah air kita) akan jauh meningkat baik kualitas maupun kuantitas.

2. Jika produksi mengalami kegagalan, seluruh resiko dipikul penanam dalam direct investment dan sebagian besar dipikul penanam dalam joint enterprise atau joint venture.

3. Para pekerja Indonesia memperoleh kesempatan dan dapat membiasakan diri dengan pekerjaan-pekerjaan mutakhir (alih teknologi).

4. Bila perjanjian kontrak telah habis mau tidak mau segala peralatan menjadi milik 
perusahaan kita, sehingga perusahaan yang sejenis akan berlangsung terus dengan pengolahan dan pendayagunaannya $\quad 100 \%$ Indonesia.

5. Atau para pekerja tersebut memperoleh cukup pengalaman serta ketrampilan untuk membangun perusahaan nasional yang sejenis yang mungkin lebih baik dan lebih terarah bagi peningkatan pembangunan di daerah lainnya, dengan demikian mereka itu dapat menjadi pioneer pelaksana proyek-proyek mutakhir di daerah- daerah di tanah air kita atau memutakhirkan perusahaan-perusahaan nasional yang telah ada di daerah-daerah.

6. Devisa negara kita akan meningkat jumlahnya, pendapatan penduduk perkapita meningkat dan produk-produk kebutuhan rakyat banyak akan mudah diperoleh dipasaran dengan mutu yang lebih menigkat.

\subsection{Perumusan Masalah}

Berdasarkan latar belakang yang telah dikemukakan di atas dapat diberikan rumusan masalah sebagai berikut:

1. Bagaimana kedudukan dan pengaturan pendirian perusahaan Penanaman Modal Asing (PMA) Di Indonesia?

2. Bagaimana tata cara Penerapan Penanaman Modal Asing (PMA) di Indonesia?

3. Bagaimana upaya pemerintah jika ada pelanggaran hukum dalam Penanaman Modal Asing (PMA) di Indonesia?

\subsection{Tujuan Penelitian}

Adapun yang menjadi tujuan penulis dalam mengadakan penelitian ini adalah sebagai berikut :

1. Untuk mengetahui kedudukan dan pengaturan pendirian perusahaan Penananam Modal Asing (PMA) di Indonesia.

2. Untuk mengetahui tata cara penerapanPenanaman Modal Asing (PMA) di Indonesia.

3. Untuk mengetahui upaya pemerintah jika ada pelanggaran hukum dalam Penanaman Modal Asing (PMA) di Indonesia.

\section{METODE PELAKSANAAN}

\section{Jenis Penelitian}

Jenis penelitian yang digunakan penyusun adalah Penelitian Normatif penelitian perpustakaan ini merupakan penelitian yang mengkaji studi dokumen, yakni menggunakan berbagai data sekunder seperti peraturan perundang-undangan, keputusan pengadilan, teori hukum, dan dapat berupa pendapat para sarjana.

2. Metode Penelitian Lapangan ( Field Research )

Metode penelitian Lapangan adalah metode dimana penulis langsung kelapangan untuk mengetahui bagaiaman perlindungan hukum bagi penanam modal asing. Penelitian ini di lakukan melalui: wawancara ataupun pengumpulan data melalui pengamatan langsung di DinasPenanaman Modal dan PelayananTerpadu Satu Pintu (DPMPTSP) Kota Medan. 


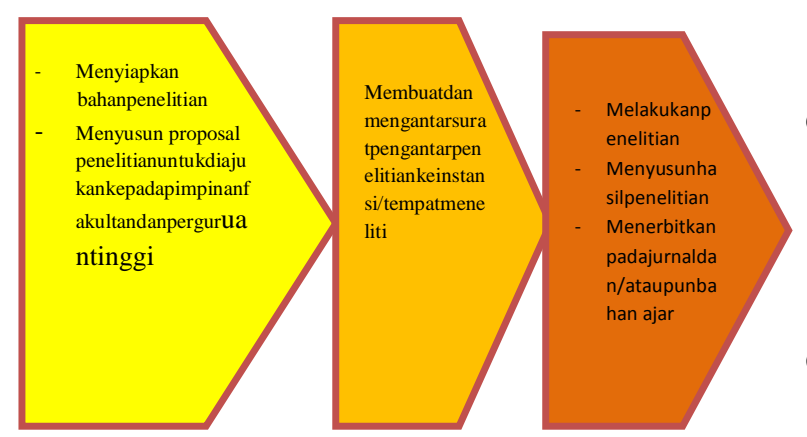

\section{HASIL DAN PEMBAHASAN}

\section{Kedudukan Dan Pendirian Perusahaan Penanaman Modal Asing Di Indonesia}

Untuk lebih jelasnya berikut ini akan diuraikan proses aplikasi penanaman modal sesuai dengan ketentuan dalam Pasal 2 Keppres Nomor 33 Tahun 1992 Sebagai Berikut:

a. Bahwa calon penanaman modal asing yang akan mengadakan usaha dalam rangka Undang Undang Nomor 1 Tahun 1967 Jo Undang - Undang Nomor 6 Tahun 1968 TBPMDN terlebih dahulu mempelajari daftar bidang - bidang usaha yang tertutupi bagi penanaman modal yang berlaku sebagaimana dimaksud dalam Pasal 1 ayat 1, dan apabila diperlukan penjelasan lebih lanjut dapat menghubungi BKPM.

b. Setelah mengadakan penelitian Yang cukup mengenai bidang usaha yang terbuka dan lokasi proyek yang dibuktikan denga surat konfirmasi pencadangan tanah dari Gubernur Provinsi serta ketentuan - ketentuan lain yang bersangkutan, calon penanaman modal mengajukan permohonan penanaman modal kepada ketua BKPM dengan mempergunakan tata cara permohonan yang di tetapkan oleh BKPM.

c. Berdasarkan penilaian terhadap permohonan tersebutkepada presiden dengan disertai pertimbangan guna memperoleh keputusan.

d. Ketua BKPM menyampaikan tembusan surat permohonan dari pertimbangan tersebut kepada:

1). Departemen yang membina bidsng usaha penanaman modal yang bersangkutan.

\section{2). Departemen keuangan.}

c. Persetujuan/ penolakan presiden mengenai suatu permohonan modal disampaikan kepada ketua BKPM.

d. Ketua BKPM menyampaikan pemberitahuan tentang keputusan presiden tersebut dalam ayat (5) kepada calon penanam modal.

e. Ketua BKPM menyampaikan tembusan surat pemberitahuan Keputusan presiden yang berlaku juga sebagai persetujuan prinsip atau izin usaha sementara kepada:

1). Departemen yang membidangi bidang usaha penanaman modal yang bersangkutan.

2). Departemen Keuangan RI.

3). Kepada Badan Pertanahan Nasional untuk menyelesaikan hak - hak atas tanah.

4). Gubernur Provinsi BKPMD yang bersangkutan untuk koordinasi penyelesaian izin lokasi. 
f. Apabila penanaman modal telah memperoleh Keputusan Presiden berupa persetujuan penanaman modal setelah dipenuhi persyaratan yang ditetapkan, maka Ketua BKPM atas nama menteri yang bersangkutan mengeluarkan:

1). Angka pengenal importir terbatas.

2). Keputusan pemberian fasilitas/ kekeringan pajak dan bea masuk.

3). Izin kerja bagi tenaga kerja asing pendatang diperlukan.

4). Izin usaha tetap.

g. Setelah memperoleh surat pemberitahuan persetujuan presiden dari ketua BKPM, penanam modal dalam waktu yang di tetapkan menyampaikan kepada BKPM daftar induk barang - barang modal, serta bahan baku dan dan bahan penolong yang akan diimpor.

h.Berdasarkan penilaian terhadap daftar induk sebagaimana dimaksud dalam ayat (9) ketua BKPM mengeluarkan ketetapan mengenai fasilitas/ keringanan bea masuk dan pungutan impor lainnya.

i. permohonan untuk perubahan atas rencana penanaman modal yang telah memperoleh persetujuan presiden, termasuk perubahan untuk perluasan proyek, disampaikan oleh penanam modal kepada BKPM untuk mendapatkan persetujuannya dengan mempergunakan tata cara yang di tetapkan oleh BKPM.

Investor asing yang akan melakukan investasi di Indonesia (pendirian PT PMA), sangat perlu memperhatikan peraturan berikut ini:

1. Daftar Negatif Investasi sebagaimana diatur dalam Peraturan Presiden No. 39 tahun 2014 Tentang Daftar Bidang Usaha yang Tertutup dan Bidang Usaha yang Terbuka dengan Persyaratan Di Bidang Penanaman Modal ("Daftar Negatif Investasi”), yang mengatur:

a. daftar bidang usaha yang tertutup untuk invetasi (baik untuk investor domestik maupun asing); dan

b. daftar bidang usaha yang terbuka bagi investor asing, dimana bidang usaha tersebut tunduk pada beberapa pembatasan.

2. Klasifikasi Baku Lapangan Usaha Indonesia (KBLI) diatur oleh Peraturan Kepala Badan Pusat Statistik No. 57 Tahun 2009 tentang Klasifikasi Baku Lapangan Usaha. Peraturan ini menjelaskan secara rinci mengenai lingkup masingmasing bidang usaha berdasarkan nomor KBLI mereka. Peraturan ini penting bagi investor asing untuk mengecek apakah pendirian PT PMA mereka di Indonesia tunduk pada pembatasan berdasarkan Daftar Negatif Investasi.

3. Pedoman dan prosedur perizinan dan non perizinan invetasi modal asing di Indonesia diatur oleh peraturan kepala Badan 
Koordinasi Penanaman Modal Indonesia (BKPM), No. 5 Tahun 2013 yang telah diubah dengan peraturan BKPM No. 12 Tahun 2013 tentang Pedoman dan Tata Cara Perizinan dan Nonperizinan Penanaman Modal ("Perka BKPM"). peraturan ini termasuk seluruh norma, standard,

4. Prosedur dan kriteria terkait dengan bentuk PT PMA di Indonesia, yang diwajibkan oleh BKPM, sebelum PT PMA dapat mulai kegiatannya, perlu memenuhi seluruh persyaratan yang diatur dalam peraturan ini.

5. UU Perseroan Terbatas mengatur persyaratan umum perseroan terbatas dan berlaku juga untuk PT PMA, yang tidak diatur dalam Perka BKPM.

\section{Tatacara Penerapan Penanaman Modal Asing (PMA) Di Indonesia}

Apabila kita mengkaji ketentuan dalam pasal 1 dan pasal 23 undang - undang Nomor 1 Tahun 1967 Tentang Penanaman Asing dalam pasal 2 ayat 1 peraturan pemerintah Nomor 20 Tahun 1994 tentang pemilikan saham dalam perusahaan yang Didirika Dalam Rangka Penanaman Modal Asing. Maka kita dapat menemukan dua bentuk Penanaman Modal Asing, yaitu:

1. Patungan antara modal asing dengan modalyang dimiliki oleh warga negara indonesia dan atau badan hukum indonesia.

Patungan adalah bersama sama mengumpulkan uang untuk suatu maksud tertentu dan

2. Langsung, dalam artian seluruh modalnya dimiliki oleh warga negara dan atau badan hukum asing.
Penanaman modal atau investor asing adalah: "perseoranganWarga negara asing, badan usaha asing, dan atau pemerintah asing, yang melakukan penanaman modal di wilayah Negara Republik Indonesia.

Dalam praktiknya, apabila terlihat bahwa ada kantor perwakilan perusahaan asing (KPPA) di indonesia, yang bisa dikatakan bahwa ada badan hukum asing yang beroperasional di Indonesia dimana operasionalnya memperoleh penguatan dan mengacu pada SK BKPM Nomor 22/SK/2001 tentang ketentuan pelaksanaan keputusan Presiden No. 90 Tahun 2000 tentang Kantor perwakilan perusahaan asing.

Apabila dikaji secara cermat, bisa dikatakan bahwa SK BKPM Nomor 22/SK/2001 ini tidak bertentangan dengan peraturan perundangan pada tingkat atasnya, yaitu pasal 3 UndangUndang Nomor 1 Tahun 1967 sebab keberadaan KPPA tidak dimaksudkan untuk menjalankan perusahaan tersendiri dan bersifat sementara, justru KPPA ini ditujukan untuk mendorong proses investasi asing agar berjalan dengan baik. Dalam SK BKPM Nomor 22/SK/2001tentang Kantor Perwakilan Perusahaan Asing untuk medirikan kantor perwakilanya di Indonesia.

Dalam pasal 5 ayat (2) Undang Undang Nomor 25 Tahun 2007 tetang penanaman modal telah ditentukan secara jelas tentang bentuk hukum perusahaan penanaman modal asing. Penanaman modal asing wajib dalam perseroan terbatas. Secara lengkap, bunyi pasal 5 ayat (2) Undang Undang Nomor 25 Tahun 2007 tentang penanaman modal yaitu: “ penanaman modal asing wajib dalam bentuk perseroan terbatsa berdasarkan hukum Indonesia dan berkedudukan di dalam wilayah negara Republik Indonesia, 
kecuali ditentukan Oleh Undang Undang".

Unsur yang melekat dalam ketentuan meliputi:

a. Bentuk hukum dari Perusahaan penanaman Modal asing adalah perusahaan terbatas (PT).

b. Didasarkan pada hukum Indonesia.

c. Berkedudukan di dalam wilayah negara Republik Indonesia.

3. Upaya Pemerintah Jika Ada Pelanggaran Hukum Dalam Penanaman Modal Asing Di Indonesia

a. Pemerintah Melakukan

Koordinasi Kepada

BKPM(Berdasarkan Pasal 27

dan pasal 28 . UU Nomor 25

Tahun 2007).Dalam rangka

koordinasi pelaksanaan

kebijakan dan pelayanan

penanaman modal tersebut,

BKPM mempunyai tugas dan

fungsi sebagai berikut:

1). Melaksanakan tugas dan koordinasi pelaksanaan kebijakan di bidang penanaman modal.

2). Mengkaji dang mengusulkan kebijakan pelayanan penanaman modal.

3). Menetapkan norma, standar, dan prosedur pelaksanaan kegiatan dan pelayanan penanaman modal.

4). Mengembangkan peluang dan potensi penanaman modal di daerah dengan memberdayakan badan usaha.
5). Membuat peta penanaman modal Indonesia.

6).Mempromosikan penanaman modal.

7). Mengembangkan sektor usaha penanaman modal melalui pembinaan penanaman modal, antara lain meningkatkan kemitraan, meningkatkan daya saing, menciptakan persaingan usaha yang sehat, dan menyebarkan informasi yang seluas luasnya dalam lingkungan penyelenggaraan penanaman modal.

8). Membantu penyelesaian berbagai hambatan dan konsultasi permasalahan yang dihadapi penanam modal dalam menjalankan kegiatan penanaman modal.

9). Mengoordinasi penanam modal dalam negri yang menjalankan kegiatan penanaman modalnya di luar wilayah Indonesia.

10). Mengoordinasi dan melaksanakan pelayanan terpadu satu pintu.

b. Pemerintah Melakukan Musyawarah Dan Mufakat Maupun Melalui Arbitrase Dan Alternatif.

Di lihat Dalam Pasal 32 UU No. 25 Tahun 2007 menjelakan tentang sebagai berikut:

a. Dalam hal terjadinya sengketa di bidang penanaman modal antara pemerintah dengan penanam 
modal, para pihak terlebih dahulu menyelesaikan sengketa tersebut melalui musyawarah dan mufakat.

b. Dalam hal menyelesaikan sengketa sebagaimana di maksud pada ayat (1) tidak tercapai, penyelesaian sengketa dapat dilakukan melalui arbitrase atau alternatif penyelesaian sengketa ataua pengadilan sesuai dengan ketentuan peraturan perundang undangan.

c. Dalam hal terjadi sengketa di bidang penanaman modal antara pemerintah dengan penanam modal dalam negri, para pihak dapat menyelesaikan sengketa tersebut melalui arbitrase tidak disepakati, penyelesaian sengketa tersebut akan dilakukan di pengadilan.

d. Dalam hal terjadinya sengketa di bidang penanaman modal antar pemerintah dengan penanam modal asing, para pihak akan menyelesaikan sengketa tersebut melalui arbitrase internasional yang harus disepakati oleh para pihak.

\section{KESIMPULAN}

Berdasarkan uraian yang dipaparkan , maka penulis menarik kesimpulan sebagai berikut:

1. Dalam Kedudukan Penaman Modal Asing di Indonesia adalah berbentuk perusahan atau Perseroan Terbatas (PT). Sesuai atau menurut Undang Undang Nomor 40 Tahun 2007 tentang perseroan terbatas, dan pendirian Perusahaan Penanaman Modal Asing harus melakukan pengajuan permohonan izin prinsip ke Pelayanan Terpadu Satu Pintu (PTSP)\&Badan Koordinasi Penanaman Modal (BKPM) agar
Penanaman Modal Asing dapat mendirikan Perusahaannya di Indonesia.

2. Dalam Proses tata cara Penerapan Penanaman Modal Asing di Indonesia harus mempunyai bentuk bentuk Penanaman Modal Asing(PMA) yang berupa bentuk patungan maupun langsung, perusahaan asing di Indonesia harus mempunyai badan hukum di Indonesia tidak memberlakukan badan hukum asing di Indonesia,namun modal badan hukum sebagian ataupun Seluruhnya boleh dimiliki oleh pihak asing. Hak dan kewajiban PMA di Indonesia juga di atur dalam Undang - undang sehingga tidak ada perbuatan semena - mena yang dilakukan PMA di Indonesia.

3. Dalam masuknya Pernanaman Modal Asing (PMA) ke Indonesia cenderung mengalami masalah masalah ataupun kendala - kendala yaitu: perusahaan melanggar hak hak buruh dan perusahaan tidak melakukan ataupun melaksanakan ketentuan lingkungan hidup yang terkait dengan pelaksanaan penanaman modal di bidang usaha yang disetujui dalam izin prinsip penanaman modal. Pemerintah juga melakukan upaya terhadap pelanggaran hukum yang di lakukan penanaman modal asing di Indonesia dengan cara melakukan koordinasi ke Badan koordinasi Penanaman Modal (BKPM)dengan berdasarkan Pasal 27 dan Pasal 28 Undang Undang Nomor 25 Tahun 2007 tentang penanaman modal, dan pemerintah juga melakukan musyawarah dan mufakat terhadap PMA maupun melalui Arbitrase Dan Alternatif dalam penyelesaian sengketa sesuai dengan Pasal 32 
Undang - Undang Nomor. 25 Tahun 2007.

\section{Saran}

Berdasarkan penelitian yang telah dilakukan penulis, maka penulis memberikan saran yang diharapkan dapat memberi manfaat bagi perkembangan perjanjian pemborongan di masa yang akan datang, sebagai berikut:

1. Sebaiknya pemerintah lebih memerhatikan ataupun mempermudah pendirian perusahaan penanaman modal asing di Indonesia. Pemerintah sepatutnya lebih memperhatikan perkembangan perusahaan asing di Indonesia, karena dengan adanya Penanaman Modal Asing(PMA) masuk ke Indonesia salah satunya adalah menguntungkan bagi Indonesia juga menambah devisa negara dan menambah lapangan pekerjaan di Indonesia dan juga dapat mengurangi angka pengangguran di Indonesia dan menambah wawasan pekerja Indonesia.

2. Sebaiknya pemerintah lebih tertuju bagaimana membuat regulasi yang mendukung perkembangan PMA di Indonesia agar perusahaan asing lebih berkembang pesat dan lebih maju. Pemerintah juga seharusnya memberikan dispensasi di dalam membuat Laporan Kegiatan Penanaman Modal (LKPM) lebih dari 3 bulan karena setiap perusahan itu pasti mengalami kendala dalam membuat LKPM ke Kepala BKPM. karena itu juga termasuk waktu yang sangat cepat bagi Perusahaan Penanaman Modal Asing.

3. Sebaiknya pemerintah di dalam melakukan upaya ataupun koordinasi ke BKPM (Badan Koordinasi Penanaman Modal) jika ada masalah
PMA di Indonesia lebih cepat menanggapinya karena dengan adanya PMA masuk ke Indonesia lebih cenderung menghasilkan manfaat yang banyak bagi Indonesia, seperti manfaat dalamsektor pertumbuhan ekonomi masyarakat maupun meningkatkan kemajuan dalam sarana dan prasarana, menambah pemasukan bagi negara, nilai jual produk dalam negeri ikut terangkat, terjalinya hubungan kerjasama bilateral maupun multilateral baik antara pemerintah Indonesia terhadap negara asing ataupun perusahaan dalam negeri maupun perusahaan asing

\section{DAFTAR PUSTAKA}

\section{A. Buku - Buku}

Ahmad M. Ramli, Status Perusahaan Dalam Hukum Perdata Internasional Teori dan Praktek, Mandar Maju, Bandung: 1994

Aminuddin Ilmar, hukum penanaman moda asing di Indonesia, kencana Prenada Media Group, Jakarta: 2006.

An An Chandrawulan, Hukum Perusahaan Multinasional Liberalisasi

HukumPerdagangan

Internasiona, PT Alumni, Bandung: 2014.

David Kairupan , aspek- aspek huku penanaman modal asing di Indonesia, kencana Prenada Media Group, Jakarta: 2013.

Hs Salim dan sutrisno Budi, Tinjauan umum tentang Penanaman Modal Asing, PT. Raja Grafindo Perasada, Jakarta: 2014

Husni Syawali dan Neni Sri Imaniyanti, Kapita Selekta Hukum 
Perusahaan, Mandar Maju, Bandung: 2000

H. Salim dan Budi Sutrisno, Hukum Investasi Di Indonesia, PT. Raja Grafindo Persada, Rajawali Pers, Jakarta: 2014

I.G. Rai Widjaya, Penanaman Modal, Jakarta: 2005

Ikeriyanti Tifani, Penananaman Modal Asing, kencana Prenada Media Group,Jakarta: 2013

Salim Hs dan Budi Sutrisno, Hukum Investasi Di Indonesia, PT Raja Grafindo Persada, Jakarta: 2008

Sentosa Sembiring, Hukum Investasi, Penerbit Nuansa Aulia, Bandung: 2007

Sihombing Jonker, hukum penanaman modal di indonesia.PT Alumni, Jakarta : 2009.

Sumantoro, Aspek Pengembangan Dunia Usaha Di Indonesia, Bina Cipta, Bandung: 1986

\section{B. Peraturan Perundang - Undangan} Undang - Undang R.I.Nomor 1 Tahun 1967 Tenatng Penanaman Modal

Undang- undang R.I.Nomor 25 Tahun 2007 Tentang Penanaman Modal

Undang - Undang Nomor 40 Tahun 2007 Tentang Perseroan Terbatas

\section{Internet}

http://bem-

umk13.blogspot.co.id/2012/ 07/makalah-penanamanmodal-asing-di.html. diakses tanggal 15/04/2018. jam 07:28.pm.

http://ondyx.blogspot.co.id/2014/01/ pengertian-penanaman- modal-asing-pma.html.di akses tanggal 24/04/2018. jam14:27.pm.

http://www.gomarketingstrategic.co $\mathrm{m} / 2016 / 06 /$ pengertianpenanaman-modal-asingpma.html. diakses tanggal 22/04/2018. jam 08:30.pm.

http://digilib.unila.ac.id/8271/2/bab \%20II. Pdf. Diakses tanggal 30/04/2018. Jam 14:27.pm. diakses tanggal 30/04/2018. Jam 15:17.pm. 